\title{
Effect Of Using Pomegranate Peel Extract As Feed Additive On Performance, Serum Lipids And Immunity Of Broiler Chicks Asmaa T Yaseen ${ }^{1}$, Magdy El-Said H El-Kholy ${ }^{1}$, Walaa M Abd El-Razik ${ }^{2}$ and Mohamed H Soliman ${ }^{3}$
}

\author{
'Dept. of Nutrition and Clinical Nutrition, Faculty of Vet. Medicine, Zagazig University' Egypt \\ ABSTRACT
}

An experiment was conducted to study the effect of dietary supplementation with pomegranate peel (Punica granatum L) extract (PPE) on growth performance, serum lipids day old Cobb broiler response as serum lysozyme content in broiler chickens. A total of 90 , one group allotted into 3 chicks were used. Birds were allotted into three experimental groups; each fed on basal diet subgroups, 10 chicks /replicate. Group I was fed on basal diet, group II was supplemented with weekly. Body weight $\mathrm{g}$ PPE $/ \mathrm{kg}$ of the diet. Body weight and feed intake were determined group were slaughtered for FCR were calculated. After the end of the trial, 3 birds from each differences $(\mathrm{P}<0.05)$ between all gron of the blood. The result of the showed no significant Liver, heart and abdominal fat all groups in body weight, weight gain, feed intake and FCR. group III. Total cholesterol and L decreased $(\mathrm{P}<0.05)$ in group $\mathrm{II}$ and significantly increased $(\mathrm{P}<0.05)$ in group II and while HDL- cholesterol concentration were cholesterol were significantly decreased $(\mathrm{P}<0.05)$ in group III, also triglycerides and VLDLwas significant increased $(\mathrm{P}<0.05)$ in group Key words: pomegranate,

\section{INTRODUCTION}

Pomegranate peel, a waste product of the pomegranate industry with higher antioxidant levels than the juice itself, an attractive candidate as a nutritional supplement for animals feed. Pomegranate peel extract had high antioxidant capacity, considering the scavenging or preventive capacity against super oxide anion, hydroxyl and peroxyl radical. Pomegranate fruit peel exerted diverse pharmacological functions as antioxidant activity $(1,2)$. Feeding pomegranate extract (POMx) rich in poly phenols affect on performance, health, nutrient digestion, and immuno competence of calves in the first $70 \mathrm{~d}$ of age. Feeding POMx had no effect on intake or BW gain in the first $30 \mathrm{~d}$ of age, but after 30 d of age, both grain dry matter intake and BW gain decreased with increasing addition of POMx. Feeding POMx did not influence dry matter, organic matter, or starch digestibility, but it reduced crude protein and fat digestion (3). PPE was reported as anti-obesity agent in a mouse model of high-fat diet induced obesity and hyper lipidemia, also PPE decrease serum total cholesterol (TC), tri glycerides (TG), glucose levels and TC/HDL-cholesterol, this may be due to inhibition of pancreatic lipase enzyme that will cause inhibition of intestinal fat absorption (4). Pomegranate fruit rind powder (PGFRP) at the dose of $100 \mathrm{mg} / \mathrm{kg}$ orally as aqueous suspension was found to stimulate the cell-mediated and humeral (5). 


\section{MATERIALS AND METHODS}

Ninety, one day old chicks of a commercial meat type (Cobb 500) cbtained from a local hatchery were used in this study. On arrival they were weighed and randomly allocated to equal three treatment groups. Each contained three replicates and each replicate contained ten chicks. Birds were reared in a naturally ventilated open house with saw dust as litter and at a density 10 birds $/ \mathrm{m} 2$. Continuous lighting and suitable temperature was provided throughout the experiment. All the chicks were vaccinated against Newcastle, avian influenza and Gamboro diseases. The basal diet was formulated according to the requirements (6) during starter period (021 day in which the bird fed diet contained CP $23.04 \%$ and ME $3203.784 \mathrm{kcal} / \mathrm{kg}$ diet) and Grower- Finisher period (22-42 day in which the bird fed diet contained CP $20.1 \%$ and $\mathrm{ME}$ $3200.358 \mathrm{kcal} / \mathrm{kg}$ diet).

\section{Table 1. Physical and chemical composition (\%) of the experimental diets used in
experimental stages}

Feed ingredients

Experimental diets

\begin{tabular}{lcc} 
& Starter & Grower-Finisher \\
\hline Yellow corn & 57.2 & 63.5 \\
Soybean meal, 48\% & 25.3 & 2.6 \\
Corn gluten, 60\% & 6.5 & 3.5 \\
Fish meal, 65\% & 3.75 & 2.5 \\
Soybean oil & 3.5 & 3.2 \\
Calcium carbonate & 1.2 & 1.2 \\
Calciumdibasic phosphate & 1.5 & 1.5 \\
Common sall & 0.3 & 0.3 \\
Premix & 0.3 & 0.3 \\
DL- Methionine, 98\% & 0.2 & 0.18 \\
Lysine, Hcl, 78\% & 0.15 & 0.12 \\
Toxenil & 0.1 & 0.1 \\
\hline
\end{tabular}

Table (2) show The experimental design

\begin{tabular}{ll}
\hline Group & \multicolumn{1}{c}{ Dief used } \\
\hline 1 & $\begin{array}{l}\text { Basal standard diet without additives } \\
\text { Basal standard diet with PPE } 0.5 \mathrm{~kg} / \\
\text { ton diet }\end{array}$ \\
3 & $\begin{array}{l}\text { Basal standard diet with PPE } 1 \mathrm{~kg} / \\
\text { ton diet }\end{array}$ \\
\hline
\end{tabular}

Growth performance parameters: Chicks were weighed weekly to determine body weight, also amount of feed consumption. Body weight gain (BWG) and feed conversion ratio (FCR) were calculated.

Carcass traits: At the end of the experimental period three birds from each group were selecied randomly, fasted over night, weighed then slaughtered by sharp knife to complete bleeding, followed by plucking the feather, evisceration and finally weighted to detect the dressing percentage. The dressed carcass weight, liver, gizzard, intestine, heart and spleen, bursa and abdominal tat were weighted and calculated as percent of life body weight.

Blood samping, biochemical analysis and immunological parameter: samples were collected at age of 1 and 42 day. At 1 day samples were collected from slaughtering 5 birds selected randomly, samples collected into clean centrifuge tube without anticoagulant for separation of serum, the sera obtained were used for lysozymes to measure ievel of humeral innate immunity. At 42 day 3 
birds per group selected randomly, samples were collected from slaughtering into clean centrifuge tube without anticoagulant for separation of serum; the sera obtained were used for lysozymes and biochemical analysis. Total cholesterol, triglycerides, HDL, LDL and VLDL were measured (7). Lysozymes activity in the serum was measured by agarose gel cell lysis assay, the method described by (8).

Preparation of pomegranate peels extract

Pomegranate peels were collected after removing peel from local pomegranate fruit. The peels were dried by hot air oven at $40{ }^{\circ} \mathrm{C}$ till the moisture content became about $8 \%$ (dry basis). The moisture content was determined by using oven drying at $105{ }^{\circ} \mathrm{C}$ until constant weight was achieved. The peels were grounded then used for extraction (9).

\section{Anti oxidants extraction Procedures}

The extraction yield of antioxidant compounds from plant materials is influenced mainly by the conditions under which the process of liquid-solid extraction is carried out to separate a soluble fraction from a permeable solid.

The dried powder sample of pomegranate peel was extracted by maceration in ethanol $70 \%$ (polar solvent with a dielectric constant of 24). The solvent was added to the dried and ground peel in glass flask with glass cover at ratio 10:1 as begin with ratio $4: 1$ and the residue was re extracted 3-4 times until it is exhausted during maceration they were applied into a thermostatic water bath shaker at room temperature for 48 hrs. The liquid extract was separated from solids by vacuum enhanced filtration through Whatman No. 1 filter paper. The alcohol was removed from the filtrate by using high-capacity evaporator (EYELA Rotary vacuum evaporator system). The ethanol free extract was dried by using lyophilizer. The dried extracts were collected and weighted to calculate the percent of extract yield $(9,10)$. The dried extracts were kept in dark at $4^{\circ} \mathrm{c}$ until used.

Statistical analyses: All the data were analyzed using the general linear model of (11).

\section{RESULTS AND DISCUSSION}

Table 3. Effect of the dietary supplementation with pomegranate peel extract (PPE) on overall performance of broiler chicks (means $\pm \mathrm{SE}$ )

\begin{tabular}{lccc}
\hline \multirow{2}{*}{ Parameters } & \multicolumn{3}{c}{ Experimental groups } \\
\cline { 2 - 4 } & Control & $\mathbf{0 . 0 5 \%}$ pomegranate & $\mathbf{0 . 1} \%$ pomegranate + \\
+cont $\mathbf{~}$ & cont \\
\hline Final bodv weight, g & $2134.17 \pm 81.86$ & $2307.50 \pm 67.84$ & $2126.25 \pm 78.66$ \\
Absolute weight gain, g & $2088.50 \pm 81.68$ & $2261.17 \pm 68.7$ & $2079.25 \pm 79.53$ \\
Total feed consumption, g & $3290.12 \pm 116.9$ & $3360.67 \pm 106.36$ & $3126.24 \pm 42.10$ \\
Overall FCR & $1.58 \pm 0.05$ & $1.49 \pm 0.002$ & $1.51 \pm 0.04$ \\
\hline
\end{tabular}

The obtained result showed that no significant differences $(\mathrm{P}<0.05)$ between groups fed $0.05 \%$ and $0.1 \%$ PPE and control one in final body weight, absolute weight gain, total feed consumption and feed conversion ratio, while increased percent of PPE decreased body weight, weight gain, FI and FCR non significantly $(\mathrm{P}<0.05)$.

These results were agreed with (3) Feeding pomegranate extract had no effect on 
intake or BW gain in the first $30 \mathrm{~d}$ of age, but after $30 \mathrm{~d}$ of age, both grain dry matter intake and BW gain decreased with increasing addition of pomegranate extract to calves.
Feeding pomegranate extract did not influence dry matter, organic matter, or starch digestibility.

Table 4. Effect of the dietary supplementation with pomegranate peel extract (PPE) on carcass traits of broiler chicks (means $\pm \mathrm{SE}$ )

\begin{tabular}{cccc} 
& \multicolumn{3}{c}{ Experimental groups } \\
\cline { 2 - 4 } Parameters & Control & $\begin{array}{c}\mathbf{0 . 0 5 \%} \text { pomegranate } \\
\text { +cont }\end{array}$ & $\begin{array}{c}\mathbf{0 . 1} \% \text { pomegranate }+ \\
\text { cont }\end{array}$ \\
\hline Dressing \% & $69.13 \pm 1.18^{\mathrm{a}}$ & $68.60 \pm 0.15^{\mathrm{a}}$ & $67.14 \pm 0.46^{\mathrm{a}}$ \\
Intestinal \% & $4.54 \pm 0.31^{\mathrm{b}}$ & $4.89 \pm 0.14^{\mathrm{ab}}$ & $5.81 \pm 0.33^{\mathrm{a}}$ \\
Liver \% & $2.79 \pm 0.31^{\mathrm{a}}$ & $1.79 \pm 0.03^{\mathrm{b}}$ & $1.81 \pm 0.01^{\mathrm{b}}$ \\
Gizzard \% & $1.91 \pm 0.21^{\mathrm{a}}$ & $1.90 \pm 0.05^{\mathrm{a}}$ & $1.93 \pm 0.05^{\mathrm{a}}$ \\
Heart \% & $0.39 \pm 0.03^{\mathrm{a}}$ & $0.38 \pm 0.01^{\mathrm{a}}$ & $0.31 \pm 0.06^{\mathrm{b}}$ \\
Spleen \% & $0.14 \pm 0.03^{\mathrm{a}}$ & $0.13 \pm 0.02^{\mathrm{a}}$ & $0.08 \pm 0.004^{\mathrm{a}}$ \\
Bursa \% & $0.13 \pm 0.02^{\mathrm{ab}}$ & $0.17 \pm 0.002^{\mathrm{a}}$ & $0.09 \pm 0.01^{\mathrm{b}}$ \\
Abdominal fat \% & $1.14 \pm 0.029^{\mathrm{a}}$ & $0.76 \pm 0.032^{\mathrm{b}}$ & $0.75 \pm 0.027^{\mathrm{b}}$ \\
\hline
\end{tabular}

The obtained result revealed significant decrease $(\mathrm{P}<0.05)$ in liver, heart and abdominal fat percent between groups fed $0.05 \%$ and $0.1 \%$ PPE and control, while no significant differences $(\mathrm{P}<0.05)$ between them in dressing, gizzard and spleen percent.

The anti-obesity effect of PPE in a mouse model of high-fat diet induced obesity and hyper lipidemia (4).

Table 5. Effect of the dietary supplementation with pomegranate peel extract (PPE) on lipid profile of broiler chicks (means $\pm S E$ )

\begin{tabular}{lccc}
\multirow{2}{*}{ Parameters } & \multicolumn{3}{c}{ Experimental groups } \\
\cline { 2 - 4 } & Control & $\begin{array}{c}\mathbf{0 . 0 5 \%} \text { pomegranate } \\
\text { +cont }\end{array}$ & $\begin{array}{c}\mathbf{0 . 1} \% \text { pomegranate } \\
+ \text { cont }\end{array}$ \\
\hline Total cholesterol (mg/dl) & $237.22 \pm 13.99^{\mathrm{a}}$ & $168.20 \pm 2.40^{\mathrm{b}}$ & $167.28 \pm 4.11^{\mathrm{b}}$ \\
TG (mg/dl) & $92.93 \pm 0.43^{\mathrm{a}}$ & $84.97 \pm 1.01^{\mathrm{a}}$ & $73.38 \pm 5.5^{\mathrm{b}}$ \\
HDL-cholesterol $(\mathrm{mg} / \mathrm{dl})$ & $57.08 \pm 3.83^{\mathrm{b}}$ & $67.93 \pm 1.07^{\mathrm{a}}$ & $69.42 \pm 2.89^{\mathrm{a}}$ \\
LDL-cholesterol $(\mathrm{mg} / \mathrm{dl})$ & $198.72 \pm 12.46^{\mathrm{a}}$ & $117.56 \pm 2.78^{\mathrm{b}}$ & $112.54 \pm 7.74^{\mathrm{b}}$ \\
VLDL $(\mathrm{mg} / \mathrm{dl})$ & $18.59 \pm 0.09^{\mathrm{a}}$ & $16.99 \pm 0.20^{\mathrm{a}}$ & $14.68 \pm 1.10^{\mathrm{b}}$ \\
\hline
\end{tabular}

Our results revealed that total cholesterol and LDLP- cholesterol concentration in serum were significantly decreased $(\mathrm{P}<0.05)$ in groups fed $0.05 \%$ and $0.1 \%$ PPE, but HDLcholesterol concentration were significantly increased $(\mathrm{P}<0.05)$ in the same groups, while tri glycerides and VLDL- cholesterol were significantly decreased $(\mathrm{P}<0.05)$ in group fed $0.1 \%$ PPE only in compared to control group. 
PPE decrease serum total cholesterol (TC), tri glycerides (TG), glucose levels and inhibition of pancreatic lipase enzyme that will TC/HDL-cholesterol, this may be due to cause inhibition of intestinal fat absorption (4).

Table 6. Effect of the dietary supplementation with pomegranate peel extract (PPE) on lysozyme content (microgram/ml) of broiler chicks (means $\pm \mathrm{SE}$ )

\begin{tabular}{rccc}
\hline \multirow{2}{*}{ Parameters } & \multicolumn{3}{c}{ Experimental groups } \\
\cline { 2 - 4 } & Control & $\mathbf{0 . 0 5 \%}$ pomegranate & $\mathbf{0 . 1 \%} \begin{array}{c}\text { pomegranate }+ \\
\text { cont }\end{array}$ \\
$\begin{array}{l}\text { lysozyme content } \\
\text { (microgram } / \mathrm{ml} \text { ) }\end{array}$ & $0.60 \pm 0.05^{\mathrm{c}}$ & $0.86 \pm 0.03^{\mathrm{b}}$ & $1.10 \pm 0.05^{\mathrm{a}}$ \\
\hline
\end{tabular}

The obtained result show that lysozyme content $(\mu \mathrm{g} / \mathrm{ml})$ was significant increased $(\mathrm{P}$ $<0.05$ ) in groups fed $0.05 \%$ and $0.1 \% \mathrm{PPE}$ in compared to control group.

Pomegranate fruit rind powder (PGFRP) at the dose of $100 \mathrm{mg} / \mathrm{kg}$ orally as aqueous suspension was found to stimulate the cellmediated and humeral components of the immune system in rabbits (5).

\section{CONCLUSION}

In conclusion, the supplementation of broiler diets with pomegranate peel extract decreased deposition of abdominal fat and decreased accumulation of fat in liver and around heart. Also it decreased total cholesterol, TG, VLDL, LDL-cholesterol concentration in broiler serum and improved bird immunity by increasing lysozyme content in broiler serum, but it not improved broilers body weight and weight gain, so PPE can be considered as anti obesity, hypo lipidemic and immunostimulant agent.

\section{REFERENCES}

1.Li Y, Guo C, Yang J, Wei J, Xu J and Cheng $S$ (2006): Evaluation of antioxidant properties of pomegranate peel extract in comparison with pomegranate pulp extract. Food Chem. 96(2): 254-60

\section{Thring $T S, P$ Hili and $D P$ Naughton} (2009): Anti-collagenase anti-elastase and anti-oxidant activities of extracts from 21 plants. BMC Complementary and Alternative Medicine. 9: 17-27

3.Oliveira $R$ A, Narciso $C D$, Bisinotto $R$ $S$, Perdomo $M C$, Ballou $M A$ and Dreher $M$ (2010): Effects of feeding polyphenols from pomegranate extract on health growth nutrient digestion and immunocompetence of calves J. Dairy Sci. $93: 4280-4291$

4.Lei $F$, Zhang $X N$, Wang $W$, Xing $D M$, Xie $W D, S u H$ and $D u L J$ (2007): Evidence of anti-obesity effects of the pomegranate leaf extract in high-fat diet induced obese mice International Journal of Obesity 31 1023-1029

5.Ross $R$ G, Selvasubramanian $S$ and Jayasundar $\quad S \quad$ (2001): Immunomodulatory activity of Punica granatum in rabbits a preliminary study Journal of Ethnopharmacology 78 85-87

6.National Research Council (NRC) (1994): Nutrition Requirements of poultry .9th Ed. Washington DC National Academy Press. 
7.Finley PR, Schifman RN, Williams RJ and Lichti DA (1978): Cholestrol in high lipoprotein :Use of $\mathrm{Mg}+2$ /Dextran sulphate in its enzymatic measurement . clin. chem. June . 24:931-933.

8.Schltz. L A (1987): Methods in Clinical Chemistry. The C.V. Mosby Cost Louis: 742-746.

\section{Ma H, Wang $Z$, Pan $Z$ and Atungulu} $G G$ (2011): Extract of Phenolics from
Pomegranate PeelsThe Open Food Science Journal 20115 17-25

10.Fatma $L$ A $H$ (2009): Effect of Pomegranate (Punica granatum) Peels and It's Extract on Obese Hypercholesterolemic Rats Pakistan Journal of Nutrition 8 (8): 1251-1257 2009 ISSN 1680-5194

11.SAS Institute (1985): SAS user's guide. SAS Institue. Inc Cary NC27513 USA. Institute. Carg.N.C.

\section{الملخص العزبي}

تأثير استخدام مستخلص قثر الرمان كاضافات اعلافس علي الأداء ودهون الام والمناعة في بداري التسمين أسماء طه باسين، مجدي السعيد حسن الخولي، ولاء محمود عبدالرازق ، محمد حسين سليمان

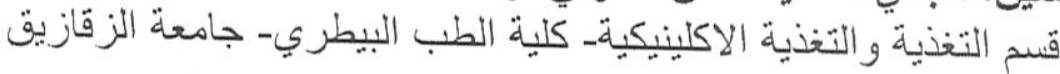

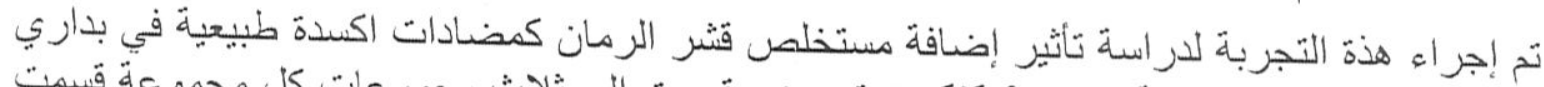

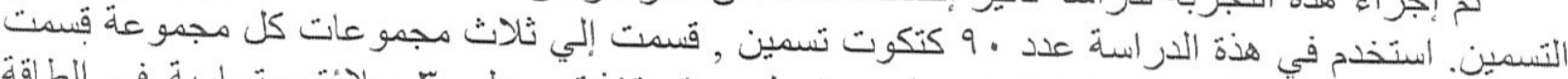

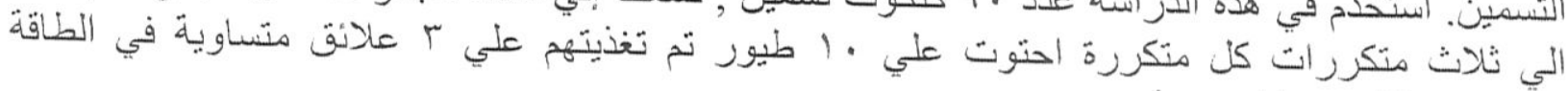

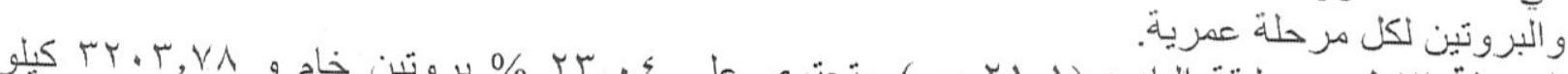

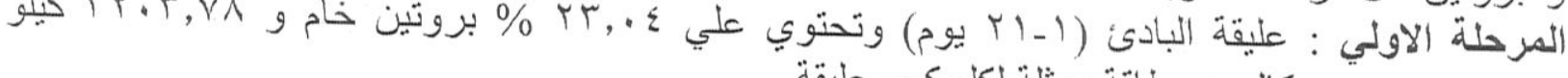
كالوري طاقة ممثلة لكل كجم عليقة.

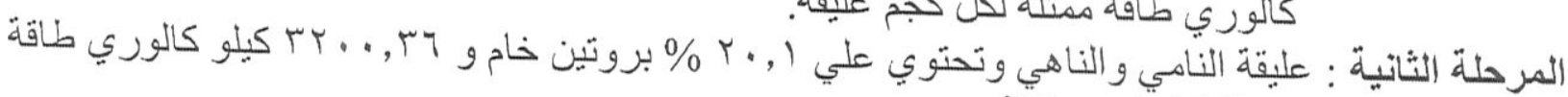
ممثلة لكل كجم عليقة.

$$
\text { وكاتت المجموعات كالاتي : }
$$

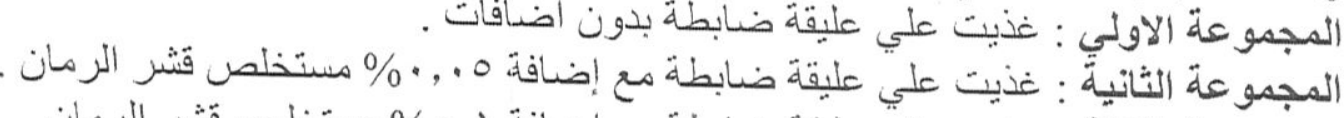

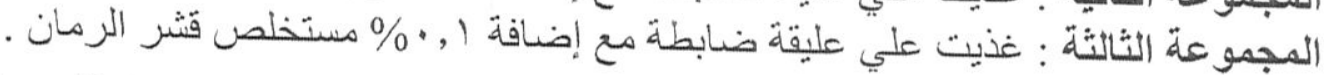

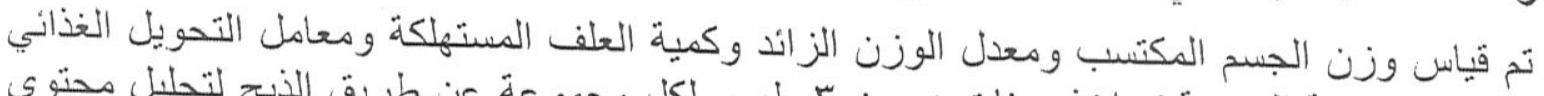

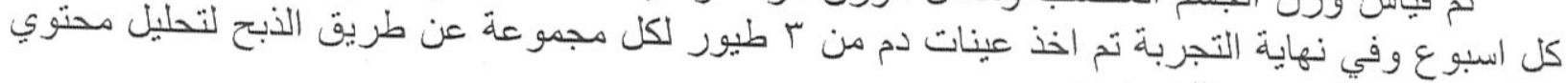

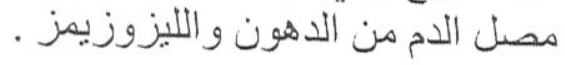

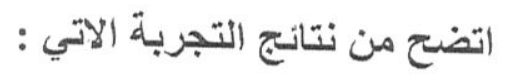

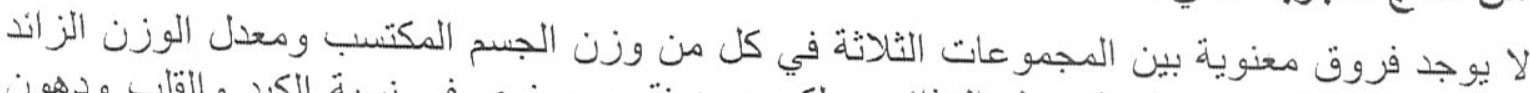

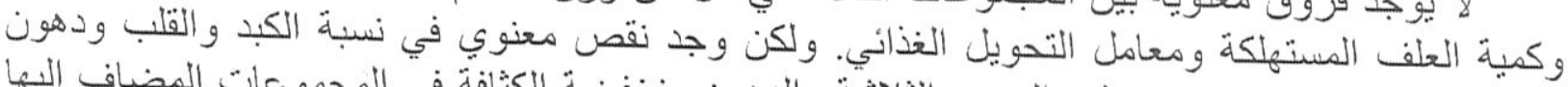

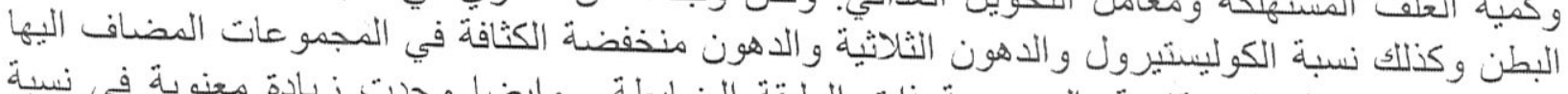

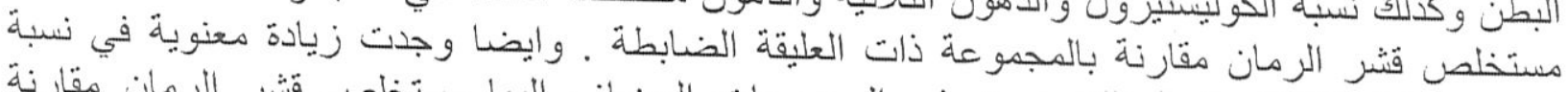

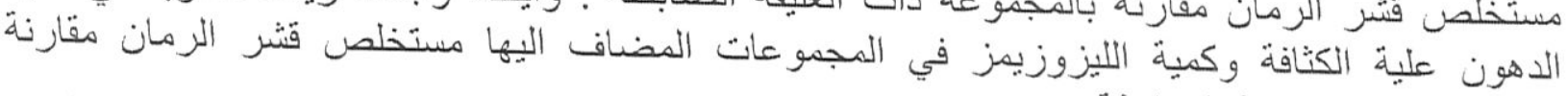
بالمجمون عة ذات العليقة الضابطة . 